\title{
植物根系分泌物对土壤污染修复的作用及影响机理
}

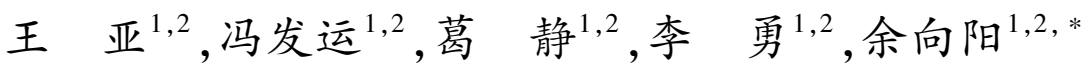 \\ 1 江苏省农业科学院农业资源与环境研究所,南京 210014 \\ 2 省部共建国家重点实验室培育基地-江苏省食品质量安全重点实验室,南京 210014
}

\begin{abstract}
摘要:生物修复是一种经济环保的土壤修复技术。根系分泌物是利用生物修复污染土壤过程中的关键物质,也是植物与土壤微 生物进行物质交换和信息传递的重要载体,在植物响应污染物胁迫中扮演重要角色。研究植物根系分泌物对土壤污染修复的 作用和影响机理, 是深人理解植物和微生物环境适应机制的重要途径,对促进生物修复污染土壤有重要指导意义。从污染物胁 迫对根系分泌物的影响、根系分泌物对土壤污染物环境行为的影响、根系分泌物在调控污染土壤中根际微生物群落结构和多样 性中发挥的作用等几个方面综述了根系分泌物对土壤污染修复的影响及内在机制。研究结果表明,根系分泌物在降低重金属 对植物的毒性、加速有机污染物降解等方面有非常重要的作用。根系分泌物对土壤微生物的丰度和多样性均有显著影响, 其与 根际微生物互作在土壤污染物的消减中发挥了重要的调控作用。在此基础上, 提出了以往研究中的不足, 并对污染物胁迫下根 系分泌物未来研究的方向和趋势进行了展望。
\end{abstract}

关键词: 污染物; 土壤微生物;根系分泌物

\section{Effects and mechanisms of plant root exudates on soil remediation}

\author{
WANG Ya ${ }^{1,2}$, FENG Fayun ${ }^{1,2}$, GE Jing ${ }^{1,2}$, LI Yong ${ }^{1,2}$, YU Xiangyang ${ }^{1,2, *}$ \\ 1 Institute of Agricultural Resources and Environment, Jiangsu Academy of Agricultural Sciences, Nanjing 210014, China \\ 2 Jiangsu Key Laboratory for Food Quality and Safety-State Key Laboratory Cultivation Base, Ministry of Science and Technology, Nanjïng 210014, China
}

\begin{abstract}
Bioremediation is an environment friendly and economically feasible remediation technology. Plant root exudates, playing an active role in root-microbe communications, are the key substances in bioremediation processes of soil contamination. Understanding the effects and mechanisms of plant root exudates on soil remediation can provide a better guidance with bioremediation techniques. Moreover, it is also helpful to understand the adapted mechanisms of plants and microbial communities in contaminated soils. In this paper, the effects of contaminants on the characteristics of root exudates, the effects of root exudates on the environmental behaviors of contaminants in soils were studied. Furthermore, the roles and mechanisms of root exudates in regulating the diversity of the rhizosphere microbial communities were also reviewed to reveal the effects and mechanisms of plant root exudates in the remediation of soil contaminants. The results indicated that root exudates played an important role in reducing the toxicity of metal (loid) s to plants, and also in accelerating the degradation of organic pollutants. Besides, root exudates had significant effects on the abundance and diversity of soil microorganisms. Interactions of root exudates with rhizosphere microorganisms played an important role in the reduction of soil contaminants. On this basis, current knowledge gaps and future research directions of root exudates under the stress of soil contaminants are also identified.
\end{abstract}

Key Words : contaminant; soil microorganism; root exudate

基金项目:国家自然科学基金项目(31772197,41701373)

收稿日期:2021-01-03; 网络出版日期:2021-10-11

*通讯作者 Corresponding author.E-mail: yuxy@ jaas.ac.cn 
土壤是地球生态系统的重要组成部分,也是人类赖以生存的物质基础,其环境质量与人体健康息息相 关 ${ }^{[1]}$ 。19 世纪以来, 全球人口急速增加, 人类活动对全球土壤系统产生的不利影响也日趋严重。其中, 以砷 $(\mathrm{As}) 、$ 采 $(\mathrm{Hg})$ 、铅 $(\mathrm{Pb})$ 、镉 $(\mathrm{Cd})$ 等重金属为代表的无机污染物及以有机氯农药 (organochlorine pesticides, OCPs)、多环芳烃 (polycyclic aromatic hydrocarbons, PAHs)、多氯联苯 (polychlorinated biphenyls, PCBs) 等为代 表的高毒高残留有机污染物已成为环境中的主要污染物 ${ }^{[1-2]}$ 。这些污染物不仅对生态环境造成直接破坏, 还 可以通过土壤迁移大量富集在农作物中, 威胁农产品质量安全和人类健康 ${ }^{[1]}$ 。土壤修复技术的开发与运用, 对于阻断污染物进入食物链和保障农业的可持续发展有重要意义。

目前,环境友好型土壤修复技术得到越来越多的关注。其中,植物-微生物联合修复技术是典型代表,该 技术因成本低、对土壤环境破坏小、无二次污染、可大面积应用等优点而持续受到关注 ${ }^{[3]}$ 。该修复技术中,根 系是联系植物与土壤微生态环境的纽带, 其分泌物对植物主动适应和抵御污染物胁迫意义重大, 是保持根际 微生态系统活力的关键因素之一 ${ }^{[4]}$ 。根系分泌物可为土壤微生物提供大量的营养物质, 是根际微生态系统 中物质迁移和能量交换的重要组成部分; 土壤中的微生物也能改善根际土壤理化性质、降低污染物的生物有 效性,从而促进植物的生长发育。我国土壤污染物的种类多、含量大、面积广, 土壤污染防治工作面临重大挑 战。根系分泌物和根际微生物在我国土壤污染治理中发挥重要作用, 系统了解根系分泌物在土壤污染修复中 发挥的作用及机理, 对于深人理解植物和微生物环境适应机制、促进植物和微生物联合修复污染土壤有重要 意义。本文以根系分泌物为切人点, 分析了污染物胁迫下植物根系分泌物的变化规律及影响因素, 研究了根 系分泌物应对污染物胁迫的响应特点, 探讨了根系分泌物在调控根际微生物群落结构和多样性中发挥的作用 及机理, 结果将有助于进一步了解污染物、根系分泌物及根际微生物之间的相互作用关系及机制, 为土壤污染 修复技术的健康发展与合理应用提供参考。

\section{1 我国土壤污染的成因、污染物种类及主要来源}

土壤具有一定的自净能力,若进人土壤的污染物超过其自净作用的负荷, 即形成土壤污染。我国用世界 $7 \%$ 的耕地面积养育了世界 $21 \%$ 的人口,为控制作物病虫害发生、促进粮食和农业稳产高产,每年向耕地投人 的农药和化肥用量远高于世界平均水平, 导致耕地板结、土壤酸化、作物药害、农产品残留超标、环境污染等一 系列问题 ${ }^{[5]}$ 。另外,化石燃料的燃烧、汽车尾气排放、矿山开采、金属冶炼等工农业行为和人类活动也持续向 环境中输人了大量污染物,导致环境污染问题日益严峻,对我国居民身体健康造成极大威胁。

2014 年环境保护部和国土资源部公布的数据显示,我国土壤总的超标率为 $16.1 \%$ 。污染类型以无机型 为主, 有机型次之, 复合型污染比重较小 ${ }^{[6]}$ 。无机污染物以 $\mathrm{Cd} 、$ 镍 $(\mathrm{Ni}) 、 \mathrm{As}$ 为主, 超标率分别达 $7.0 \% 、 4.8 \%$ 和 $2.7 \%$; 有机污染物以六六六 (hexachlorocyclohexane, HCH) 、滴滴涕 (dichlorodiphenyltrichloroethane, DDT) 和 $\mathrm{PAHs}$ 为主, 点位超标率分别为 $0.5 \% 、 1.9 \%$ 和 $1.4 \%$ 。根据土地的不同利用类型进行划分, 耕地土壤环境状况 也不容乐观, 点位超标率达 $19.4 \%$, 主要污染物为 $\mathrm{Cd} 、 \mathrm{Ni}$ 、铜 $(\mathrm{Cu}) 、 \mathrm{As} 、 \mathrm{Hg} 、 \mathrm{~Pb} 、 \mathrm{DDT}$ 和 $\mathrm{PAHs}$ 。

土壤中污染物的来源主要分为自然源和人为源两个部分。以砷为例, 自然来源的砷主要来自火山爆发和 矿石风化, 其中又以斜方砷铁矿 $\left(\mathrm{FeAs}_{2}\right)$ 、雄黄 $\left(\mathrm{As}_{4} \mathrm{~S}_{4}\right)$ 、雌黄 $\left(\mathrm{As}_{2} \mathrm{~S}_{3}\right)$ 、砷黄铁矿 ( $\left.\mathrm{FeAsS}\right)$ 等含砷矿物风化为

主 $^{[7]}$ 。人为来源的砷主要包括采矿、冶炼、化石燃料的燃烧以及含砷农药、杀虫剂、除草剂、防腐剂的使用。 工业革命以前, 人类活动对土壤环境的影响范围和深度较小。进人工业化社会以来, 随着我国经济的持续高 速发展, 规模庞大的工农业生产活动对土壤的污染和破坏也开始急剧增加。污水灌溉、工业固废排放及农药 化肥的长期不合理施用等一系列人类行为成为我国土壤中污染物的主要来源 ${ }^{[8]}$ 。

\section{2 根系分泌物的定义、组成及功能}

根系分泌物通常是指植物在其生长发育过程中通过根系向根际环境中释放的有机化合物的总称 ${ }^{[9]}$, 是 一种成分复杂的非均相体系。狭义的根系分泌物指植物通过溢泌作用进人土壤的可溶性物质 ${ }^{[10]}$ 。广义的根 
系分泌物主要包括: (1) 渗出物, 即由根部细胞通过扩散方式释放的有机物, 大部分低分子量有机物均通过该 方式进人环境中; (2) 分泌物, 即由根细胞通过主动运输方式释放的具有一定生理功能的有机物, 对营养元素 迁移、信号传递、植物解毒、抵御胁迫等起重要作用; (3) 排泄物,一般指根细胞代谢产生的代谢产物; (4)黏胶 质及脱落物,指根冠细胞、未形成次生壁的表皮细胞和根毛释放的黏胶状物质以及脱落的根毛、细胞碎 片等 ${ }^{[11]}$ 。

根系分泌物按种类进行划分, 主要有糖类、氨基酸类、酚酸类、甾醇类、有机酸、脂肪酸等 $($ 表 1 )。根系分 泌物按分子量还可分为高分子量与低分子量分泌物,前者主要是多糖、多聚半乳糖醛酸、高分子黏胶物质和胞 外酶类; 后者主要包括低分子有机酸 (柠檬酸、苹果酸、草酸、醋酸等)、可溶性糖类( 葡萄糖, 木糖,果糖,麦芽 糖, 蔗糖, 半乳糖, 核糖等)、酚酸类(对差基苯甲酸、丁香酸、香豆酸、肉桂酸、香草酸、阿魏酸等)、氨基酸(精氨 酸、赖氨酸、亮氨酸、苯丙氨酸等) 及无机化合物 (二氧化碳、质子、阳离子、阴离子等 $)^{[10,12]}$ 。

\section{表 1 根系分泌物中的主要化合物}

Table 1 The major compounds present in root exudates

\begin{tabular}{|c|c|}
\hline 分类 Classification & 化合物 Compounds \\
\hline 糖类 Saccharide & 葡萄糖、果糖、核糖、蔗糖、木糖、鼠李糖、阿拉伯糖、低聚糖、聚多糖、岩藻糖、半乳糖、麦芽糖、棉子糖 \\
\hline $\begin{array}{l}\text { 氨基酸类 } \\
\text { Amino acid }\end{array}$ & $\begin{array}{l}\text { 精氨酸、赖氨酸、组氨酸、亮氨酸、天冬氨酸、天冬酰胺、谷氨酸、谷氨酰胺、脯氨酸、苯丙氨酸、丙氨酸、色氨 } \\
\text { 酸、异亮氨酸、半胱氨酸、胱氨酸、 } \gamma \text {-氨基丁酸、丝氨酸、甲硫氨酸、甘氨酸、苏氨酸、煔氨酸 }\end{array}$ \\
\hline $\begin{array}{l}\text { 酚酸类 } \\
\text { Phenol }\end{array}$ & $\begin{array}{l}\text { 对着基苯甲酸、4 -差基苯乙酸、香豆酸、丁香酸、香草酸、阿魏酸、肉桂酸、咖啡酸、杏仁酸、原儿茶酸、水杨 } \\
\text { 酸、藜芦酸 }\end{array}$ \\
\hline 甾醇类 Sterol & 油菜素甾醇、胆甾醇、谷甾醇、豆甾醇、豆甾烷醇 \\
\hline $\begin{array}{l}\text { 有机酸 } \\
\text { Organic acid }\end{array}$ & $\begin{array}{l}\text { 醋酸、柠檬酸、草酸、苹果酸、酒石酸、乳酸、丙酸、丙二酸、己二酸、丙酮酸、丁酸、丁二酸、反丁烯二酸、戊 } \\
\text { 酸、戊二酸、羟基乙酸、顺丁烯二酸 }\end{array}$ \\
\hline 脂肪酸 Fatty acid & 油酸、亚油酸、亚麻酸、硬脂酸、软脂酸、棕㭣酸 \\
\hline 酶类 & 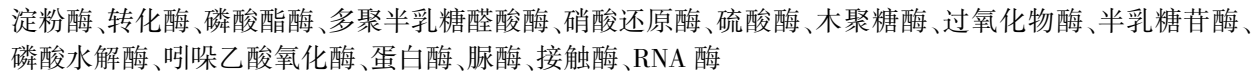 \\
\hline $\begin{array}{l}\text { 生长因子 } \\
\text { Growth factor }\end{array}$ & $\begin{array}{l}\text { 植物生长素、生物素、烟酸、泛酸、胆碱、肌醇、硫胺素、尼克酸、维生素 B1、维生素 B5、维生素 B6、维生素 H、 } \\
\text { 对氨基苯甲酸 }\end{array}$ \\
\hline $\begin{array}{l}\text { 其他 } \\
\text { Others }\end{array}$ & $\begin{array}{l}\text { 二氧化碳、乙烯、质子、核苷、尿核苷、㿝苷、黄酮类化合物、植物抗毒素、多肽、苂光物质、葡萄糖苷、氢㲵 } \\
\text { 酸、有机磷化物、铁载体、腺嘌呤、鸟嘌呤、胞二磷胆碱、独脚金内酯 }\end{array}$ \\
\hline
\end{tabular}

根系分泌物的种类繁多, 其组成和含量受光照、温度、土壤养分含量、土壤微生物组成、植物种类及生长发 育阶段等因素的影响,并导致其功能多样。根系分泌物的主要功能包括: (1) 改善营养胁迫; (2) 化感作用; (3) 养分供给, 根系分泌物可为土壤微生物提供碳源、氮源和能源 ${ }^{[13]}$; (4) 信号传导, 类黄酮、多糖、有机酸、氨 基酸、酚类、独脚金内酯等多种根系分泌物可作为信号物诱导特定微生物在植物根系定殖 ${ }^{[10-11,14]}$; (5) 降低 污染物毒性,植物分泌的小分子有机化合物 (如有机酸、氨基酸、多肽等) 具有较强的络合或鳌合能力 ${ }^{[9]}$, 可与 重金属离子相互作用并使其转化为无毒或毒性较小的形态滞留在根外,从而缓解重金属对植物的毒害 ${ }^{[15]}$; 另 外,大分子黏胶类物质具有强吸附性能, 可以吸附土壤中的污染物, 减少其移动性和毒性 ${ }^{[9]}$ 。

\section{3 植物根系分泌物对污染物胁迫的响应及机理}

根是植物的营养器官, 植物通过根系从土壤中摄取生长代谢所需的养分和水分, 同时通过根系向土壤释 放分泌物影响土壤环境。根系分泌物在改良土壤质地、改善根际微生态系统及植物抵御各类逆境胁迫中发挥 了重要作用 ${ }^{[10]}$,通过调控根系分泌物应对污染物胁迫是植物对生存环境长期适应的结果。

3.1 根系分泌物对重金属胁迫的响应机制

3.1.1 重金属胁迫对根系分泌物的影响

重金属污染土壤中,植物根系分泌的有机酸、氨基酸、糖类、酶类等均可能发生改变。目前,对重金属胁迫 下植物根系分泌物的研究主要集中于有机酸。有机酸带有一个或多个羧基官能团,不仅在细胞代谢中起重要 
作用,在植物对重金属的解毒中也发挥了不可替代的作用。

重金属污染胁迫下根系分泌物的变化与植物种类和基因型密切相关。如表 2 所示,铝 $(\mathrm{Al})$ 胁迫下,不同 植物分泌的主要有机酸种类存在差异。大麦 (Hordeum vulgare L.) 根系分泌苹果酸、柠檬酸和琥珀酸, 小麦 (Triticum aestivum L.) 根系分泌苹果酸, 水稻 (Oryza sativa L.) 根系分泌柠檬酸, 玉米 (Zea mays L.) 根系分泌柠 檬酸、苹果酸,菾麦 (Fagopyrum esculentum Moench.) 根系分泌草酸, 油菜 (Brassica rapus L.)、燕麦 (Avena sativa L.) 和萝卜 (Raphanus sativus L.) 根系分泌柠檬酸或苹果酸 ${ }^{[16]}$ 。不同植物对 $\mathrm{Al}$ 的耐性与有机酸的分泌存在相 关性 ${ }^{[16]}$ 。通常 $\mathrm{Al}$ 耐受品种的有机酸分泌量显著高于 $\mathrm{Al}$ 敏感品种, 这是由于有机酸鳌合环境介质中游离态 的 $\mathrm{Al}$ 离子, 减少了 $\mathrm{Al}$ 与细胞壁或质膜结合 ${ }^{[17]}$ 。也有研究表明 $\mathrm{Al}$ 胁迫可诱导 $\mathrm{Al}$ 耐受和敏感水稻或玉米品种 分泌大量柠檬酸, 且品种间柠檬酸含量没有显著差异 ${ }^{[18-19]}$, 说明分泌有机酸可能不是水稻或玉米品种抗 $\mathrm{Al}$ 的主要机制。同一种植物的不同基因型根系分泌物也存在差异。对东南景天 (Sedum alfredii Hance) 的研究 发现,Cd 胁迫下矿山型与非矿山型东南景天体内的有机酸种类相同,但含量差异较大。

表 2 铝对不同植物根系分泌物组成与含量的影响

Table 2 The effects of aluminum on composition and content of root exudates in different plants

\begin{tabular}{|c|c|c|c|}
\hline $\begin{array}{l}\text { 植物 } \\
\text { Plant }\end{array}$ & $\begin{array}{l}\text { 根系分泌物组成 } \\
\text { Composition of root exudates }\end{array}$ & $\begin{array}{l}\mathrm{Al} \text { 胁迫下根系分泌物的含量变化 } \\
\text { The variation of root exudates after } \mathrm{Al} \text { exposure }\end{array}$ & $\begin{array}{c}\text { 文献来源 } \\
\text { Literature resources }\end{array}$ \\
\hline $\begin{array}{l}\text { 大麦 } \\
\text { Barley }\end{array}$ & 苹果酸、柠檬酸、琥珀酸、草酸 & $\begin{array}{l}\text { 苹果酸、柠檬酸和琥珀酸含量显著增加, 草酸含量无变 } \\
\text { 化; } \mathrm{Al} \text { 耐受品种较 } \mathrm{Al} \text { 敏感品种苹果酸、柠檬酸和琥珀酸 } \\
\text { 的分泌量显著增加 }\end{array}$ & {$[17]$} \\
\hline $\begin{array}{l}\text { 小麦 } \\
\text { Wheat }\end{array}$ & $\begin{array}{l}\text { 酮龙二酸、柠檬酸、苹果酸、琥珀酸、富 } \\
\text { 马酸 }\end{array}$ & $\mathrm{Al}$ 耐受品种较 $\mathrm{Al}$ 敏感品种苹果酸分泌量显著增加 & {$[20]$} \\
\hline $\begin{array}{l}\text { 小麦 } \\
\text { Wheat }\end{array}$ & 苹果酸 & $\begin{array}{l}\mathrm{Al} \text { 耐受品种苹果酸分泌量显著增加, } \mathrm{Al} \text { 敏感品种苹果 } \\
\text { 酸分泌量无变化 }\end{array}$ & {$[21]$} \\
\hline $\begin{array}{l}\text { 小麦 } \\
\text { Wheat }\end{array}$ & 苹果酸、磷酸 & $\mathrm{Al}$ 耐受品种较 $\mathrm{Al}$ 敏感品种苹果酸、磷酸的分泌量增加 & {$[22]$} \\
\hline $\begin{array}{l}\text { 水稻 } \\
\text { Rice }\end{array}$ & 柠檬酸 & 柠檬酸分泌量显著增加 & {$[18]$} \\
\hline $\begin{array}{l}\text { 玉米 } \\
\text { Maize }\end{array}$ & 柠檬酸、苹果酸、磷酸 & $\begin{array}{l}\mathrm{Al} \text { 耐受品种较 } \mathrm{Al} \text { 敏感品种柠檬酸、苹果酸和磷酸的分 } \\
\text { 泌量显著增加 }\end{array}$ & {$[23]$} \\
\hline $\begin{array}{l}\text { 玉米 } \\
\text { Maize }\end{array}$ & 柠檬酸、苹果酸 & $\begin{array}{l}\mathrm{Al} \text { 耐受品种柠檬酸、苹果酸的分泌量显著增加, } \mathrm{Al} \text { 敏感 } \\
\text { 品种无变化 }\end{array}$ & {$[24]$} \\
\hline $\begin{array}{l}\text { 荠麦 } \\
\text { Buckwheat }\end{array}$ & 草酸 & $\mathrm{Al}$ 耐受品种草酸的分泌量显著增加 & {$[25]$} \\
\hline $\begin{array}{l}\text { 绿杨 } \\
\text { Evergreen poplar }\end{array}$ & $\begin{array}{l}\text { 草酸、柠檬酸、琥珀酸、乳酸、乙酸等 } 5 \\
\text { 种有机酸; 谷氨酸、甘氨酸、天门冬氨酸 } \\
\text { 等 } 17 \text { 种氨基酸 }\end{array}$ & $\begin{array}{l}\mathrm{Al} \text { 胁迫浓度增加, 草酸、柠檬酸、有机酸总量呈增加趋 } \\
\text { 势, 琥珀酸、乳酸、乙酸含量先增加后降低, 酪氨酸和脯 } \\
\text { 氨酸先增加后趋于平稳, 其他 } 15 \text { 种氨基酸均先增加后 } \\
\text { 降低 }\end{array}$ & {$[26]$} \\
\hline
\end{tabular}

重金属种类也可能影响根系分泌的有机酸种类或数量。林海涛等发现 $\mathrm{Pb}$ 和 $\mathrm{Cd}$ 胁迫对茶树 (Camellia sinensis L.) 根系分泌有机酸的种类没有影响, 但对有机酸的分泌量有显著影响 ${ }^{[27]}$ 。 Yang 等研究发现, Cd、Cu、 $\mathrm{Ni}$ 和 $\mathrm{Pb}$ 胁迫下, 高冰草 (Agropyron elongatum) 根系分泌的有机酸种类和含量均存在差异, 其中 $\mathrm{Cu}$ 胁迫可诱 导苹果酸、草酸和柠檬酸的分泌量显著增强, $\mathrm{Cd}$ 和 $\mathrm{Ni}$ 可诱导该植物根系分泌苹果酸和草酸,但其含量较 $\mathrm{Cu}$ 胁迫时显著减少, $\mathrm{Pb}$ 胁迫下有机酸含量均未显著增加 ${ }^{[28]}$ 。此外, 重金属胁迫浓度对根系分泌的有机酸含量 也有影响,一般呈现低促高抑的趋势 ${ }^{[29]}$ 。比如 $1 \mathrm{mg} / \mathrm{L} \mathrm{Cu}$ 处理下, 高冰草根系分泌的苹果酸含量随胁迫时间 增加显著增加; 当 $\mathrm{Cu}$ 处理浓度增加至 $50 \mathrm{mg} / \mathrm{L}$, 其根系分泌的苹果酸含量随胁迫时间显著下降 ${ }^{[28]}$ 。然而, 也 有研究表明,随着重金属胁迫浓度或胁迫时间的增加,有机酸的分泌量可能会持续增加 ${ }^{[26,30]}$ 。

重金属胁迫下,植物根系分泌物除有机酸外,氨基酸、糖类、多肽及部分次生代谢物的种类或含量也可能

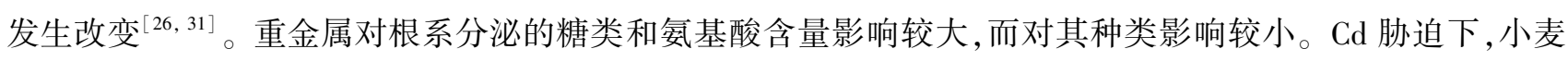
根系分泌的糖类随 $\mathrm{Cd}$ 胁迫浓度增加而增加, 氨基酸种类没有发生变化但分泌量呈现先增加后降低趋势 ${ }^{[31]}$ 。 
$\mathrm{Al}$ 胁迫浓度增加也导致龙眼 (Dimocarpus longana) 幼苗糖类分泌量增加、氨基酸的分泌量先增加后下降。与 $\mathrm{Cd}$ 胁迫不同, 高浓度 $\mathrm{Al}$ 可能导致氨基酸分泌种类减少 ${ }^{[32]}$ 。与有机酸相比, 氨基酸、糖类及多数次生代谢物 在重金属解毒中发挥的作用和机制尚不明确。以氨基酸为例,氨基酸是土壤有机氮的重要来源,也是土壤微 生物的重要营养源 ${ }^{[33]}$ 。微生物能以氨基酸为底物合成植物生长调节剂促进植物生长, 微生物的代谢物也会 影响植物分泌氨基酸 ${ }^{[34]}$ 。因此, 重金属胁迫下,一方面植物可能通过氨基酸分泌影响根际微生物的种类、数 量及活性等,间接影响植物对重金属的解毒; 另一方面,氨基酸 (比如半胱氨酸、组氨酸等) 可与重金属离子形 成稳定的螯合物, 降低重金属的有效性, 从而缓解重金属对植物的毒害 ${ }^{[35]}$ 。通常情况下植物分泌的氨基酸含 量远低于有机酸 ${ }^{[26]}$,所以可能不是植物重金属解毒的主要途径。

3.1.2 根系分泌物应对重金属胁迫的响应机制

重金属进人土壤后, 通过吸附、溶解、沉淀、凝聚、络合等各种反应, 形成不同的赋存形态, 并表现出不同的 环境效应和生物毒性。根据植物对不同形态重金属吸收难易程度,将土壤中重金属分为可交换态 (被吸附 态)、碳酸盐结合态、铁锰氧化物结合态、有机物结合态和残渣态 ${ }^{[36]}$ 。根系分泌物可能通过影响根际土壤 $\mathrm{pH}$ 值、土壤中重金属的赋存形态、溶解性等方式调控植物对重金属的吸收。这些作用方式又可能受到重金属的 种类、理化性质、赋存形态、根系分泌物的种类等因素的影响 ${ }^{[37-38]}$ 。图 1 总结了根系分泌物对土壤重金属环 境行为的主要影响 ${ }^{[9]}$ 。

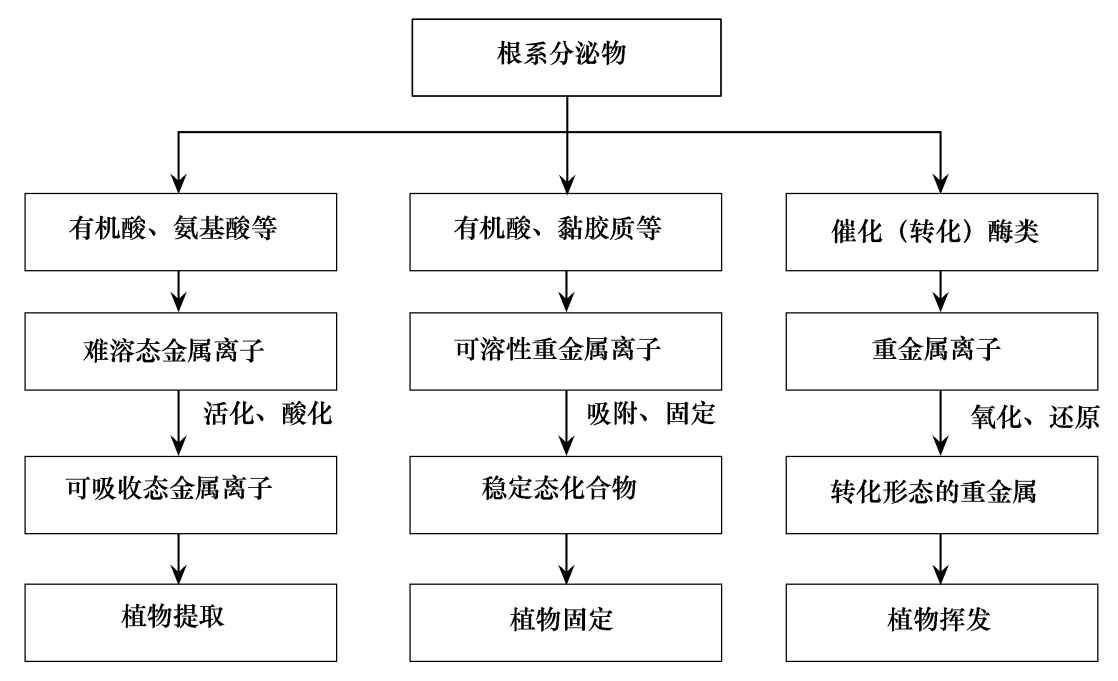

图 1 根系分泌物对土壤重金属环境行为的影响

Fig.1 Effect of root exudates on the environmental behaviors of heavy metal(loid) $s$ in soils

根系分泌物可以通过影响重金属离子在根一土界面的吸附-解吸、配位-解离、氧化-还原等过程, 改变重金 属的赋存形态及有效性, 最终影响植物对重金属的吸收 ${ }^{[39]}$ 。研究表明, 根系分泌物可以与土壤固相中的重金 属离子竞争吸附位点, 通过增加或减少重金属离子在固相上的吸附调控土壤溶液中重金属离子浓度 ${ }^{[40]}$ 。对 于土壤中的变价重金属, 植物根系可以释放氧气、分泌氧化物或催化酶类将这些重金属氧化, 比如将 $\operatorname{As}$ (III) 氧化为 $\operatorname{As}(\mathrm{V})$ 、将 $\operatorname{Cr}(\mathrm{III})$ 氧化为 $\operatorname{Cr}(\mathrm{VI})$ 等, 从而改变重金属的毒性和生物有效性 ${ }^{[41]}$ 。

根系分泌物可以通过还原、酸化、鳌合等作用方式活化土壤中难溶态重金属, 从而促进植物对重金属的吸 收。有机酸是目前研究较多的根系分泌物组分, 主要通过酸溶解、络合溶解和还原活化 3 个方面影响重金属 的含量和形态 ${ }^{[42]}$,进而影响重金属有效性。重金属有效性与有机酸的化学性质有关,也因重金属性质、土壤 理化条件、植物种类以及水肥条件等而异。当环境中的重金属含量对植物的正常代谢活动不构成影响或某类 植物对特定重金属具有极强的耐性和积累能力时, 植物可以通过根系调控分泌物的组成或含量, 提高根际土 壤微生物数量和酶活性 ${ }^{[9]}$, 或大量分泌 $\mathrm{H}^{+}$, 降低根际土壤 $\mathrm{pH}^{[43]}$, 增加矿质营养元素和重金属的有效性, 从而 
促进植物对重金属的吸收利用。蜈蚣草 (Pteris vittata L.) 、东南景天、向日葵 (Helianthus annuus L.) 等超积累 植物在重金属污染土壤修复中有较好的应用前景 ${ }^{[44-46]}$ 。超积累植物富集重金属的主要机制之一是增加根系 有机酸的分泌, 降低根际土壤 $\mathrm{pH}$ 值, 从而促进其对重金属的吸收利用 ${ }^{[47]}$ 。这是由于土壤中大部分重金属以 残渣态赋存, 随着土壤 $\mathrm{pH}$ 值降低, 重金属的溶解度不断增强, 导致其生物有效性增加。对砷超积累植物蜈蚣 草的研究证实, 其砷超富集能力与根系分泌物中含大量植酸和草酸有关 ${ }^{[44]}$, 这些有机酸可以促进土壤中难溶 砷化合物 (砷酸铁、砷酸钲等) 的溶解, 从而促进其对砷的吸收。吴丽萍等的研究也表明, 有机酸对 $\mathrm{Cu} 、 \mathrm{Cr}$ 、 $\mathrm{Cd} 、 \mathrm{~Pb} 、 \mathrm{Zn}$ 等重金属的溶出有促进作用 ${ }^{[42]}$ 。此外, 根系分泌物可以与重金属离子螯合,形成 “重金属-低分子 量有机酸” 鳌合物 ${ }^{[48]}$, 这些螯合物不易被土壤固相吸附, 故其迁移能力得到增强, 从而促进植物对重金属的 吸收。

根系分泌物也可以与重金属离子结合并形成稳定的化合物,减少植物对重金属的吸收。研究表明,当环 境中重金属的含量对植物代谢和生长发育产生明显影响、甚至产生毒害效应时,会诱导植物激活其防御反应, 通过调节根系分泌物的组成和含量, 提高土壤 $\mathrm{pH}$ 值 (减少 $\mathrm{H}^{+}$分泌)、增加土壤固相对重金属的吸附或与重金 属形成不易被植物吸收利用的络合物或螯合物 ${ }^{[49]}$, 从而降低重金属元素在土壤中的移动性、减少植物对重金 属的吸收,进而减轻重金属对其造成的毒害 ${ }^{[17]}$ 。根系分泌物与重金属的络合能力大小与重金属的性质有关, 比如小麦根系分泌物对 $\mathrm{Pb}$ 的络合能力大于 $\mathrm{Cd}^{[50]}$ 。

3.2 根系分泌物对有机污染物胁迫的响应机制

3.2.1 有机污染物胁迫对根系分泌物的影响

根系分泌物是植物响应外界胁迫的重要途径,植物对土壤中有机污染物的耐受能力往往与根系分泌物密 切相关。相同胁迫条件下, 植物根系分泌物的释放特征及其主要组分的种间差异主要取决于植物基因型及其 生理状态 ${ }^{[51]}$ 。当植物种类相同, 而有机污染物的种类、胁迫浓度及胁迫时间存在差异时, 植物的根系分泌特 征较为复杂。通常, 有机污染物胁迫均可诱导植物分泌更多的有机酸、氨基酸和糖类 ${ }^{[52-53]}$, 这可能与污染物 胁迫改变根细胞的选择透过性有关 ${ }^{[54]}$ 。有机污染物的种类及其胁迫程度的差异可能导致根系分泌物的组成 和含量呈现不同的变化规律。总体来看, 有机污染物胁迫对根系分泌的小分子化合物组成无明显影响, 浓度 则随胁迫浓度呈现不同的变化趋势。潘声旺等 ${ }^{[55]}$ 研究表明, 苯并 (a) 萠胁迫可增强羊茅属 (Festuca) 植物根 系对可溶性糖的分泌, 随着胁迫浓度增加及胁迫时间延长, 可溶性糖分泌量呈现 “先升后降”趋势。此外, 随 着苯并 (a) 芘胁迫浓度增加, 有机酸和氨基酸的分泌量也不断增加, 但分泌的有机酸和氨基酸种类较为稳 定 ${ }^{[55]}$ 。类似的, 随着萠胁迫浓度增加, 黑麦草根系分泌的有机酸和氨基酸组成无明显变化, 但含量总体随胁 迫浓度增加而增加; 总糖分泌量同样呈现先增加后下降的趋势 ${ }^{[56]}$ 。另外, 有机污染物胁迫还可能对根际土壤 酶含量及活性产生影响。低浓度苯并 (a) 芘胁迫可提高黑麦草根际土壤中多酚氧化酶的含量, 并加速苯并 (a) 芘的降解 ${ }^{57]}$ 。然而, 高浓度苯并 (a) 芘胁迫下, 紫花苜宿 (Medicago sativa) 和黑麦草根际土壤中的脱氢酶 和多酚氧化酶活性较低浓度胁迫时显著下降 ${ }^{[57-58]}$ 。

有机污染物对根系分泌物的促进效应, 可能与植物对污染物的富集能力相关。植物对污染物的富集能力 越强, 根系受到的胁迫程度越大, 其释放的分泌物也相应增加 ${ }^{[52]}$ 。陈桐等发现, 邻苯二甲酸酯 (PAEs) 胁迫促

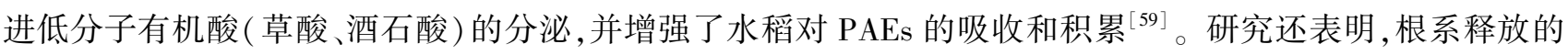
不同分泌物直接或间接参与了有机污染物的降解过程, 并且存在加和效应和协同效应 ${ }^{[55]}$, 说明根系分泌物在 植物修复中有较大的应用潜力。

\subsection{2 根系分泌物应对有机污染物胁迫的响应机制}

根系分泌物对有机污染物降解的促进效应与植物种类、根系分泌物的组成及根际微生物的作用均有关 联 $^{[60]}$ 。根系分泌物对有机污染物胁迫的响应主要有两种途径, 即直接作用和间接作用。有机污染物胁迫下, 根系分泌的酶类 (磷酸酶、脱卤素酶、过氧化物酶、漆酶等) 可以直接降解有机污染物 (有机磷杀虫剂、氯代反 应溶剂、苯酚等)。研究表明, 根系向土壤释放的酶类可以分解 PAHs、三氯乙烯( TCE)、三硝基甲苯 (TNT) 等 
多种有机污染物 ${ }^{[9,61-62]}$ 。此外, 根系分泌物还可以通过促进土壤中有机污染物的溶解、氧化还原过程及微生 物的作用间接加速有机污染物的降解 ${ }^{[13]}$ 。图 2 总结了根系分泌物对土壤有机污染物环境行为的主要影响。

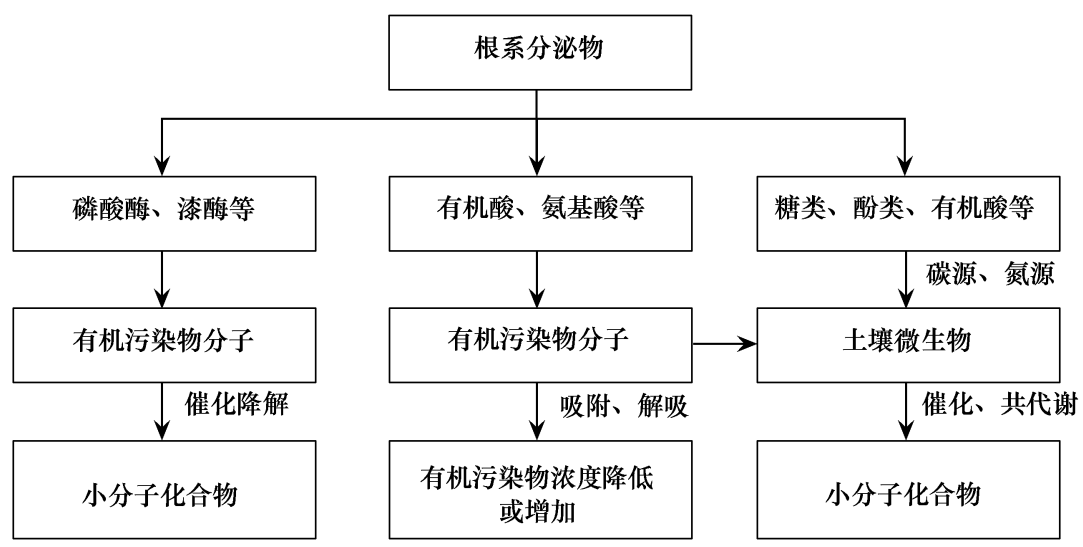

图 2 根系分泌物对土壤有机污染物环境行为的影响

Fig.2 Effect of root exudates on the environmental behaviors of organic pollutant in soils

根系分泌物可以与污染物相互作用,影响污染物在土壤固相上的吸附和解吸过程, 从而改变其生物有效 性 ${ }^{[39,63]}$ 。Gao 等研究发现, 人工合成根系分泌物 (ARE) 对土壤中的多环芳烃有明显的活化作用。随着 ARE 浓度增加, 菲和芘的解吸量显著增加 ${ }^{[64]}$ 。氨基酸和有机酸对多环芳烃均有解吸附作用, 有机酸的解吸附能力 相对更强 ${ }^{[64]}$ 。Luo 等研究表明, 添加玉米、小麦和黑麦草 (Lolium rigidum L.) 的根系分泌物均可促进土壤中 DDT 的降解, 主要原因在于它们的根系分泌物显著促进了 DDT 在土壤中的解吸 ${ }^{[63]}$ 。另外, 根系分泌物可通 过提高有机污染物的溶解性 (比如分泌鼠李糖脂等表面活性剂) ${ }^{[13]}$ 、表观溶解度, 降低有机污染物的正辛醇水分配系数等途径影响其生物有效性 ${ }^{[65]}$ 。

根系分泌物可以选择性影响根际微生物数量, 并通过改变根际微生物的群落结构和相对丰度, 诱导降解 微生物向根际富集, 或通过促进根际微生物的生长 ${ }^{[66-68]}$ 、提高降解酶基因拷贝数和活性 ${ }^{[62,69]}$, 间接加快有机 污染物的降解。Kirk 等发现石油烃类污染物胁迫下, 黑麦草 (Lolium perenne) 和紫花苜宿的根际选择性富集

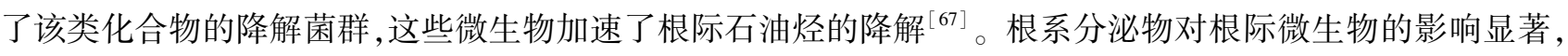
直接表现为根际土壤中微生物的数量远高于非根际土壤, 差异可达几个数量级, 这种现象称之为 “根际效 应” ${ }^{[70]}$ 。研究表明, 土壤中有机污染物的降解主要归功于细菌和真菌的作用 ${ }^{[71]}$, 其中又以细菌占主导地

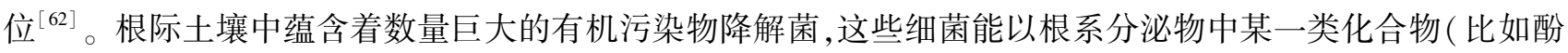
类化合物) 为唯一碳源并与之相互作用 ${ }^{[13]}$, 加速根际土壤中有机污染物的降解。根系分泌物正是通过调节这 些微生物的种群数量、群落结构及降解酶活性, 从而影响根际土壤有机污染物的环境行为 ${ }^{[71-72]}$ 。

根系分泌物还可以通过共代谢作用促进有机污染物的降解 ${ }^{[73]}$ 。微生物的共代谢指只有在初级能源物质 存在的条件下,才能进行的有机化合物生物降解过程。其中, 提供碳源或能源的物质为第 1 底物 (生长基 质), 被共代谢的污染物为第 2 底物。研究发现, 当有机污染物的苯环数量增加时 (比如 5 环或 5 环以上的 PAHs), 以污染物为唯一碳源、可完全降解污染物的细菌种类明显减少。此时, 微生物主要以共代谢方式对这 些污染物进行降解 ${ }^{[74]}$ 。研究表明, 水杨酸、邻苯二甲酸、琥珀酸等根系分泌物均可提高根际微生物活性和相 关酶活性, 促进萠或苯并 (a) 萠的共代谢降解 ${ }^{[75-76]}$, 说明根系分泌物作为难降解有机污染物的共代谢底物促 进土壤中有机污染物的降解具备可能性。

\section{4 污染物胁迫下根系分泌物介导的根际微生物区系变化机理}

土壤微生物种类丰富,主要包括细菌、真菌、放线菌、藻类和原生动物等。其中,部分微生物种类具有较强 
的污染物耐性, 它们可以通过多种作用方式影响土壤污染物的毒性、形态及生物有效性 ${ }^{[37]}$, 从而对植物抗逆 产生重要影响。植物与根际微生物有紧密的互作关系,两者相互构成植物-微生物共生体系统。

根系分泌物是植物与土壤微生物进行物质、能量和信息交流的重要载体。植物根际微生物数量远高于非 根际土壤, 是根系分泌物介导根际微生物区系变化的最有力证明。研究表明, 植物根系可以分泌对微生物有 益的氨基酸、维生素、酶等物质, 为微生物提供营养物质或作为底物吸引特定微生物在根际聚集、定殖并促进 其生长 ${ }^{[77]}$ 。根际微生物能够消耗根系分泌物中的有机物及矿质营养元素, 改变根系分泌物的种类和数量, 在 根际微域形成浓度梯度并直接促进根系分泌物的释放 ${ }^{[78]}$ 。此外, 根际微生物还能影响植物代谢过程中酶的 活性及其它成分与植物进行互作, 部分微生物能分泌胞外酶帮助植物消减环境中的污染物。污染物的种类不 同,根系分泌物介导植物根际微生物变化的机理也不尽相同。

4.1 重金属胁迫下根系分泌物介导的根际微生物变化及机理

重金属对生物体普遍具有致毒效应,土壤中的微生物也不例外。低浓度重金属对土壤微生物的抑制作用 较小, 甚至可能促进微生物的生长, 即 “毒物兴奋效应”; 随着重金属浓度增加, 其抑制效应随之增强, 因此重 金属污染加重可能导致土壤微生物的种群数量和多样性大幅下降 ${ }^{[79]}$ 。植物根系分泌物可以改善重金属胁迫 土壤中微生物的数量、活性和分布特征,并且这种调控作用与植物、微生物和重金属的种类关系密切。

不同植物品种对重金属的耐性差异较大。重金属敏感植物品种的根系分泌物可能通过与重金属形成不 易被自身吸收利用的金属鳌合物或增加土壤对重金属的吸附 ${ }^{[49]}$, 从而降低土壤中重金属的有效性; 重金属耐 受或超积累植物品种的根系分泌物可能会活化土壤中的重金属。不同植物根系重金属有效性的差异, 又进一 步导致根际微生物的种群数量和多样性发生变化。对于重金属敏感植物品种,其根际重金属有效性下降使得

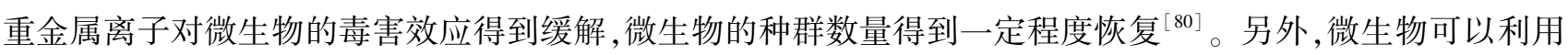
根系分泌物作为碳源、氮源、磷源、硫源和能源物质 ${ }^{[70]}$, 进一步促进自身生长, 并导致根际土壤中的微生物数 量远高于非根际土壤。对于重金属耐受植物品种, 其根际重金属有效性的增加必然对微生物种群发育产生不 利影响 ${ }^{[81]}$ 。研究表明, 重金属浓度增加可导致根际土壤细菌种群数量及多样性显著下降, 外源添加根系分泌 物可使一些微生物 (比如植物促生菌 Azotobacter) 的数量得到恢复 ${ }^{[80,82]}$ 。有意思的是, 部分细菌种类却能在 高浓度重金属污染土壤中生长良好, 使这些细菌成为根际的主要微生物类群 ${ }^{882]}$ 。除一些细菌种类外, 菌根真 菌在植物抗重金属胁迫过程中也发挥了重要作用。重金属污染环境中, 菌根真菌除通过菌丝的活动富集、络 合、针化重金属外,还可通过促进根系分泌物的释放改善根际环境条件 ${ }^{[46]}$ 。孙晨瑜等研究表明,接种菌根真 菌后黄花蒿 (Artemisia annua L.) 根系分泌物中的可溶性蛋白含量、可溶性糖含量、游离氨基酸含量均显著增 加, 有机酸的种类增多、含量显著提高 ${ }^{[83]}$ 。另一方面, 根系分泌物对菌根的形成及生长也有刺激和促进作用, 根系分泌物可以通过提高菌根侵染率和植物根系活力 ${ }^{[84]}$ 、吸引菌根真菌在根际聚集并促进其生长繁殖 ${ }^{[46]}$, 加速土壤中重金属的钝化、降低重金属的植物毒性。

重金属与微生物之间存在复杂的相互作用关系,并且受根系分泌物调控。研究发现, 不同根际微生物对 重金属有效性的影响差异较大。假单胞菌 (Pseudomonas aeruginosa) 对 $\mathrm{Pb}$ 有较强的活化作用, 而白腐真菌

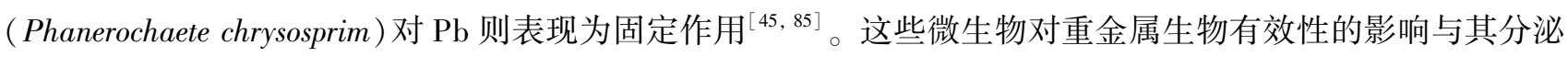

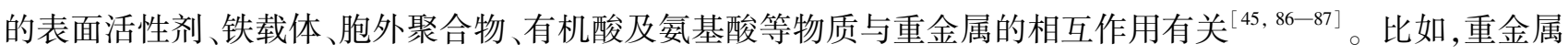

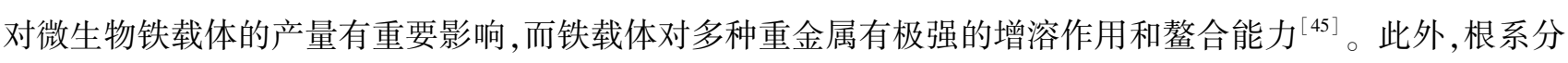
泌物可能抑制或促进微生物对重金属的活化, 说明重金属与微生物间的互作受到植物根系分泌物的调控。海 州香葶 (Elsholtzia splendens) 根系分泌物可抑制假单胞菌对 $\mathrm{Cu} 、 \mathrm{~Pb}$ 和 $\mathrm{Zn}$ 的活化, 但促进了白腐真菌对 $\mathrm{Cu}$ 和 $\mathrm{Pb}$ 的活化 ${ }^{[85]}$ 。根系分泌物对重金属的活化作用可能与其诱导微生物分泌铁载体或吸引产铁载体微生物在 根际定殖有关 ${ }^{[88]}$ 。根系分泌物在微生物与重金属互作中发挥的调控作用可能导致微生物的数量、活性、群落 结构等进一步发生改变。

综上, 根系分泌物可能通过改变土壤中重金属的形态、毒性和生物有效性影响根际微生物的群落结构, 并 
与根际微生物进行相互作用重塑根际微生物区系,其在重金属的生物地球化学循环中发挥了重要作用。

4.2 有机污染物胁迫下根系分泌物介导的根际微生物变化及机理

有机污染物大多是高度疏水的化合物, 在土壤中溶解能力差、生物可利用性普遍较低 ${ }^{[70]}$ 。一些有机污染 物还能与土壤颗粒形成复合物, 进一步降低其生物有效性, 导致土壤中有机污染物很难被植物或微生物利用, 增加了生物修复的难度。根系分泌物可以增加有机污染物的生物有效性、促进植物与微生物间的交流, 在土 壤有机污染物的消减中发挥重要作用。

当根系-土壤界面遭受有机污染物胁迫时,植物根系通常会释放出特异性分泌物 (主要包括氨基酸、有机 酸、糖类等), 在土壤环境中与微生物共同建立 “抗衡模式”, 主要过程包括: 影响污染物在根系界面的吸附、吸 收和积累等环境行为, 增强根际微生物的群落转化或诱导根际微生物群落结构的定向变化, 促进功能微生物 的生长并加速根际污染物的消减等。该模式中植物与微生物协同消减土壤环境中的有机污染物,降低了污染 物对植物根系和微生物的化学致毒效应 ${ }^{[89]}$ 。

有机污染物胁迫下, 植物根系分泌物与微生物间存在复杂的相互作用关系。首先, 根系分泌物对根际微 生物数量产生重要影响。多项研究证明,提高无色杆菌 (Achromobacter)、固氮菌 (Azotobacter) 等微生物数量可 加速土壤中甲苯、PCBs、PAEs 等有机污染物的降解、减少污染物毒性并提高植物生物量 ${ }^{[2,90-92]}$ 。根系分泌物 可作为营养和能源物质为这些微生物所用, 通过提高降解菌的数量和活性, 促进污染物在根际土壤中的降 解 ${ }^{[93-94]}$ 。其次, 根系分泌物对根际微生物的群落结构有显著影响。与微生物相比, 植物还没有进化出成熟的 应对复杂有机分子的深层降解系统 ${ }^{[13]}$, 因此植物根际倾向于富集具污染物降解功能的菌群 ( 又称为 “正向趋

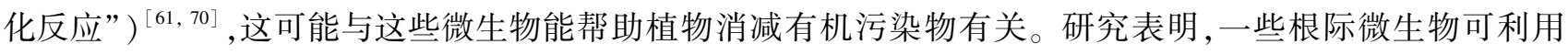
有机污染物作为唯一碳源促进自身生长 ${ }^{[67]}$, 而根系分泌物可为这些微生物提供营养和能源物质, 使得该类微 生物种群数量不断增加。与此同时, 土壤中微生物分泌的过氧化氢酶、磷酸酶、催化酶、脱氢酶、䐂酶、多酚氧 化酶等胞外酶的含量不断增加、活性得到增强 ${ }^{[39,62,93]}$, 这些胞外酶类在污染物的脱氢、脱羧基等反应中发挥 了重要作用 ${ }^{[62]}$, 导致土壤中有机污染物的浓度及有效性进一步下降。最后, 根系分泌物( 比如水杨酸、邻苯二 甲酸、琥珀酸等) 可以作为共底物, 通过调节降解基因表达和激活微生物代谢途径促进微生物降解有机污染 物 ${ }^{[2,95]}$, 这种共代谢作用在植物-微生物联合降解高分子量、难降解有机污染物 (比如萠、苯并 (a) 萠等) 时较 为常见 ${ }^{[2,75-76]}$ 。土壤微生物也能影响根系分泌物的释放 ${ }^{[78]}$ 。土壤微生物可以通过分泌次生代谢物 $(2,4-二$ 乙酰基间苯三酚、玉米烯酮等) 促进植物根系分泌更多的氨基酸 ${ }^{[34]}$, 部分土壤特异性微生物甚至可以改变植 物根系分泌的代谢产物组成 ${ }^{[96]}$ 。总之, 对根系分泌物的组成和含量产生重要影响的生物或非生物因子, 包括 植物的种类、污染物的种类和浓度、微生物对污染物的耐性和降解能力等, 均有可能重塑有机污染物胁迫下的 根际微生物区系, 进而影响有机污染物的降解。

综上, 有机污染物胁迫下, 根系分泌物可能通过影响有机污染物在土壤中的吸附与解吸过程, 从而影响有 机污染物的生物有效性; 也可能通过改变微生物的数量、种类、分布或作为底物参与微生物的共代谢进程, 进 而影响有机污染物在根际土壤中的浓度与分布特征。微生物是土壤有机污染物降解的主要驱动力 ${ }^{[97-98]}$, 植 物根系分泌物与其根际微生物的相互作用对加速土壤中有机污染物的降解、实现污染土壤的生物修复及植物 适应逆境胁迫均具有积极的意义。

\section{5 结语}

植物根系分泌物在降低重金属毒性和加速有机污染物降解等方面有非常重要的作用 (图 3)。根系分泌 物对根际微生物种类、数量和分布有显著影响, 其与根际微生物互作在污染物的消减中发挥了重要作用, 相关 研究一直是环境领域的研究热点。以往的研究不足及今后的研究方向如下:

(1) 目前的根系分泌物收集方法受环境因素影响较大, 仍无法保证根系及根际环境不被扰动。此外, 土 壤微生物活动增大了根系分泌物原位收集的难度, 这些化合物释放到根际环境后迅速被微生物消耗, 使得实 


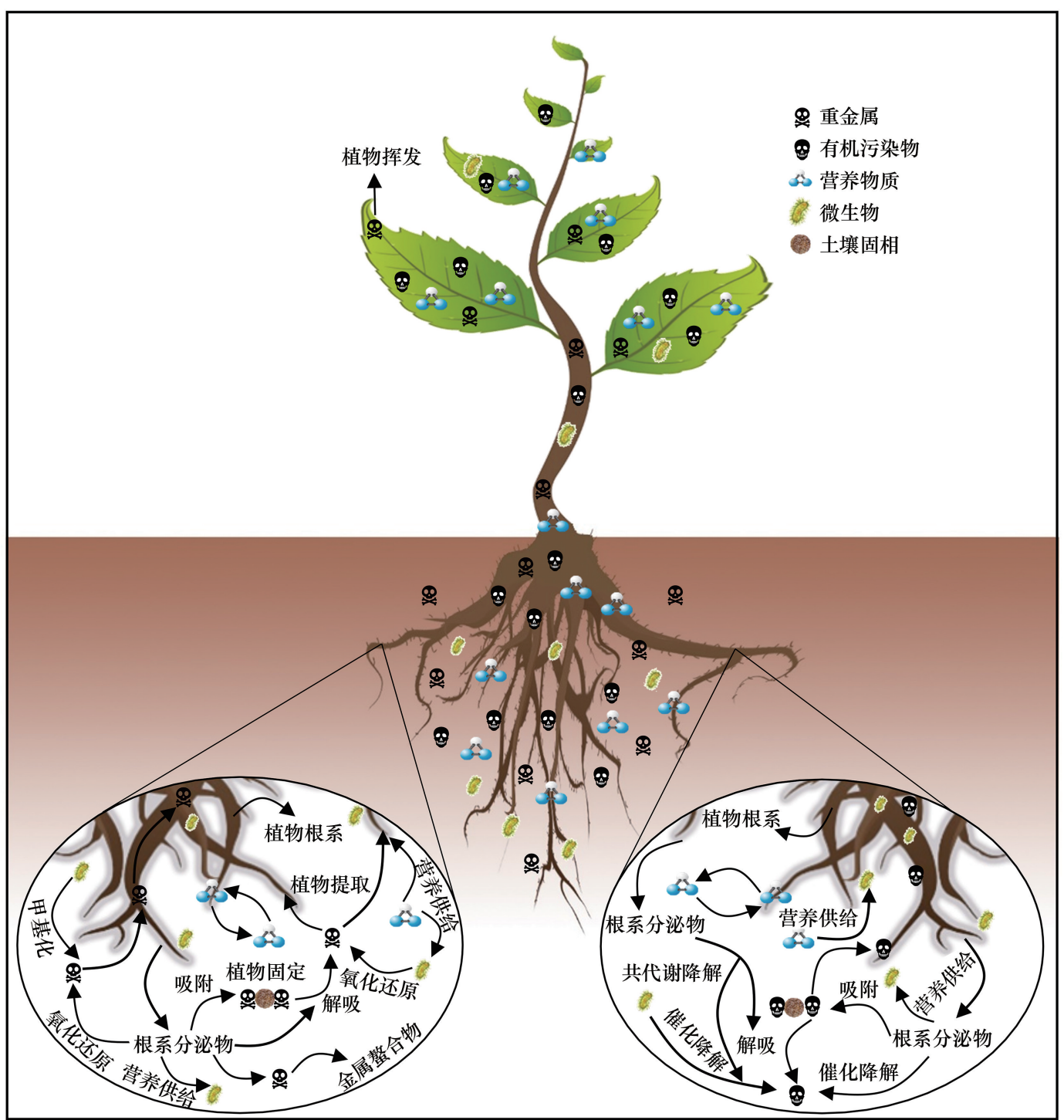

图 3 根系分泌物在重金属或有机污染土壤中发挥的主要作用概念模型

Fig.3 A conceptual model of main roles of root exudates in soils contaminated with heavy metals or organic pollutants

际土壤环境中几乎不可能原位收获根系分泌物 ${ }^{[78]}$ 。将来仍需尽快开发高效实用的根系分泌物原位收集方法 或建立同位素示踪等技术,为科学、客观地评价根系分泌物在缓解植物逆境胁迫中发挥的作用奠定基础。

(2) 利用植物-微生物联合对污染土壤进行修复是未来的研究重点。目前的研究主要关注根系分泌物变 化引起的根际微生物群落差异及其对污染物环境行为的影响,根际微生物的数量、活性变化与污染物消减的 关系等,但相关研究仍处于现象研究阶段, 缺乏对过程与机理的深人解析。未来需要进一步深人研究逆境条 件下植物 (特别是超积累植物) 根系分泌物与土壤微生物区系的关系, 明确根系分泌物调控根际微生物降解 土壤污染物的机制。植物根际微生物 (特别是降解菌群) 的时空分布特征、复合微生物对污染物的联合降解 特性、土壤中降解基因的丰度、多样性及水平转移等与根系分泌物的关系也是未来的重要研究方向。

(3) 利用内生菌进行污染物生物降解。内生菌在植物体内污染物降解中发挥作用的大小取决于进人植 物组织内部的污染物浓度, 而污染物在植物体内的迁移、分布与根系分泌物关系密切。今后的研究应重点关 注: (1) 污染物胁迫下植物根系如何调控并驱使特定微生物在根际定殖、植物内生菌群落结构的变化与根系 分泌物的关系、根系分泌物作为信号分子在内生菌趋化反应中发挥的作用及机理; (2) 植物与其根际及内生 
微生物间的分子信号通路、根系分泌物在植物-微生物联合消减污染物中发挥的作用及机理; (3) 内生菌调控 植物体内有机污染物的代谢过程中,母体化合物代谢物的毒理学评估和膳食风险评估。

(4) 以往关于根系分泌物与污染物胁迫关系的研究多集中于初生代谢物 (比如低分子量有机酸、糖类和 氨基酸等), 对于次生代谢物涉及较少,应加强次生代谢产物在污染土壤修复方面的研究。如:生物碱类、异 戊二烯类、黄酮类、酚类化合物等次生代谢物的分子结构与部分有机污染物的分子结构具有相似性,可能诱导 微生物分解代谢基因降解污染物 ${ }^{[99]}$ 。

\section{参考文献( References) :}

[1] 赵方杰, 谢婉湢, 汪鹏. 土壤与人体健康. 土壤学报, 2020, 57(1): 1-11.

[ 2 ] 傅婉秋, 谢星光, 戴传超, 吴清倩, 贾永. 植物-微生物联合对环境有机污染物降解的研究进展. 微生物学通报, 2017, 44(4): 929-939.

[ 3 ] 牛之欣, 孙丽娜, 孙铁珩. 重金属污染土壤的植物-微生物联合修复研究进展. 生态学杂志, 2009, 28 (11): 2366-2373.

[ 4 ] 吴彩霞, 傅华. 根系分泌物的作用及影响因素. 草业科学, 2009, 26(9): 24-29.

[ 5 ] 朱永官, 沈仁芳, 贺纪正, 王艳芬, 韩兴国, 贾仲君. 中国土壤微生物组: 进展与展望. 中国科学院院刊, 2017, 32(6): 554-565.

[ 6 ] Zhao F J, Ma Y B, Zhu Y G, Tang Z, Mcgrath S P. Soil contamination in China: current status and mitigation strategies. Environmental Science \& Technology, 2015, 49(2) : 750-759.

[ 7 ] 胡留杰, 白玲玉, 李莲芳, 曾希柏. 土壤中砷的形态和生物有效性研究现状与趋势. 核农学报, 2008, 22(3)：383-388.

[ 8 ] 王文兴, 童莉, 海热提. 土壤污染物来源及前沿问题. 生态环境, 2005, 14(1): 1-5.

[ 9 ] 徐炜杰, 郭佳, 赵敏, 王任远, 侯淑贞, 杨芸, 钟斌, 郭华, 刘晨, 沈颖, 柳丹. 重金属污染土壤植物根系分泌物研究进展. 浙江农林大学 学报, 2017, 34(6): 1137-1148.

[10] 吴林坤, 林向民, 林文雄. 根系分泌物介导下植物-土壤微生物互作关系研究进展与展望. 植物生态学报, 2014, 38(3): 298-310.

[11] Huang X F, Chaparro J M, Reardon K F, Zhang R F, Shen Q R, Vivanco J M. Rhizosphere interactions: root exudates, microbes, and microbial communities. Botany, 2014, 92(4) : 267-275.

[12] Gianfreda L. Enzymes of importance to rhizosphere processes. Journal of Soil Science and Plant Nutrition, 2015, 15(2) : $283-306$.

[13] Alagić SČ, Maluckov B S, Radojičić V B. How can plants manage polycyclic aromatic hydrocarbons? May these effects represent a useful tool for an effective soil remediation? A review. Clean Technologies and Environmental Policy, 2015, 17(3) : 597-614.

[14] Uroz S, Courty P E, Oger P. Plant symbionts are engineers of the plant-associated microbiome. Trends in Plant Science, 2019, 24 ( 10) : 905-916.

[15] 傅晓萍, 豆长明, 胡少平, 陈新才, 施积炎, 陈英旭. 有机酸在植物对重金属耐性和解毒机制中的作用. 植物生态学报, 2010, 34(11): 1354- 1358 .

[16] Zheng S J, Ma J F, Matsumoto H. Continuous secretion of organic acids is related to aluminium resistance during relatively long-term exposure to aluminium stress. Physiologia Plantarum, 1998, 103(2) : 209-214.

[17] Guo T R, Zhang G P, Zhou M X, Wu F B, Chen J X. Influence of aluminum and cadmium stresses on mineral nutrition and root exudates in two barley cultivars. Pedosphere, 2007, 17(4): 505-512.

[18] Ma J F, Shen R F, Zhao Z Q, Wissuwa M, Takeuchi Y, Ebitani T, Yano M. Response of rice to Al stress and identification of quantitative trait loci for Al tolerance. Plant and Cell Physiology, 2002, 43(6) : 652-659.

[19] Piñeros M A, Shaff J E, Manslank H S, Alves V M C, Kochian L V. Aluminum resistance in maize cannot be solely explained by root organic acid exudation. A comparative physiological study. Plant Physiology, 2005, 137(1) : 231-241.

[20] Basu U, Godbold D, Taylor G J. Aluminum resistance in Triticum aestivum associated with enhanced exudation of malate. Journal of Plant Physiology, 1994, 144(6): 747-753.

[21] Ryan P R, Delhaize E, Randall P J. Characterisation of Al-stimulated efflux of malate from the apices of Al-tolerant wheat roots. Planta, 1995 , 196 (1) : 103-110.

[22] Pellet D M, Papernik L A, Kochian L V. Multiple aluminum-resistance mechanisms in wheat ( roles of root apical phosphate and malate exudation). Plant Physiology, 1996, 112(2) : 591-597.

[23] Pellet D M, Grunes D L, Kochian L V. Organic acid exudation as an aluminum-tolerance mechanism in maize (Zea mays L.). Planta, 1995 , 196 (4) : 788-795.

[24] Jorge R A, Arruda P. Aluminum-induced organic acids exudation by roots of an aluminum-tolerant tropical maize. Phytochemistry, 1997, 45(4) : 675-681.

[25] Zheng S J, Ma J F, Matsumoto H. High aluminum resistance in buckwheat: I. Al-induced specific secretion of oxalic acid from root tips. Plant 
Physiology, 1998, 117(3): 745-751.

[26] 钱莲文, 李清彪, 孙境蔚, 冯莹. 铝胁迫下常绿杨根系有机酸和氨基酸的分泌. 厦门大学学报: 自然科学版, 2018, 57(2): 221-227.

[27］林海涛, 史衍坌. 铅、镉胁迫对茶树根系分泌有机酸的影响. 山东农业科学, 2005, (2) : 32-34.

[28] Yang H, Wong J W C, Yang Z M, Zhou L X. Ability of Agrogyron elongatum to accumulate the single metal of cadmium, copper, nickel and lead and root exudation of organic acids. Journal of Environmental Sciences, 2001, 13(3) : 368-375.

[29] 王玉云. Cd 胁迫对不同水稻根系分泌有机酸和氨基酸及根系 Cd 含量的影响 [D ]. 成都: 四川农业大学, 2011.

[30］黄冬芬. 水稻对土壤重金属镉的响应及其调控 [D]. 扬州: 扬州大学, 2008.

[31］张玲, 王焕校. 镉胁迫下小麦根系分泌物的变化. 生态学报, 2002, 22(4)：496-502.

[32］万泉. 铝胁迫对龙眼幼苗根区分泌物的影响. 林业科学, 2007, 43(11) : 21-26.

[33] 曹小闯, 吴良欢, 马庆旭, 金千瑜. 高等植物对氨基酸态氮的吸收与利用研究进展. 应用生态学报, 2015, 26(3): 919-929.

[34] Phillips D A, Fox T C, King M D, Bhuvaneswari T V, Teuber L R. Microbial products trigger amino acid exudation from plant roots. Plant Physiology, 2004, 136(1) : 2887-2894.

[35] Mejáre M, Bülow L. Metal-binding proteins and peptides in bioremediation and phytoremediation of heavy metals. Trends in Biotechnology, 2001, 19(2): 67-73.

[36] Tessier A, Campbell P G C, Bisson M. Sequential extraction procedure for the speciation of particulate trace metals. Analytical Chemistry, 1979, $51(7): 844-851$

[37] 李小平, 刘献宇, 徐长林, 赵亚楠, 吴婷, 刘东英, 杨涛, Yu H T. 河谷型城市土壤有害金属有机酸与细菌淋溶特性. 环境科学学报, 2016, 36(11): 4153-4163.

[38] 卢豪良, 严重玲. 秋茄 (Kandelia candel ( L) ) 根系分泌低分子量有机酸及其对重金属生物有效性的影响. 生态学报, 2007，27(10)： 4173-4181.

[39］侯芸芸. 蔍草根系分泌物在萠一铅复合污染土壤植物修复中的作用 $[D]$. 上海: 上海大学, 2016.

[40] 胡浩, 潘杰, 曾清如, 马云龙, 刘小燕. 低分子有机酸淋溶对土壤中重金属 $\mathrm{Pb} \mathrm{Cd} \mathrm{Cu}$ 和 Zn 的影响. 农业环境科学学报, 2008, 27 (4)： 1611-1616.

[41] Zhang J, Zhou W X, Liu B B, He J, Shen Q R, Zhao F J. Anaerobic arsenite oxidation by an autotrophic arsenite-oxidizing bacterium from an arsenic-contaminated paddy soil. Environmental Science \& Technology, 2015, 49(10) : 5956-5964.

[42] 吴丽萍, 白雯宇, 文科军, 李可, 危硕. 模拟根系分泌有机酸对焚烧炉渣重金属的溶出特征. 环境工程学报, 2018, 12(8): 2220-2230.

[43] Zeng F R, Chen S, Miao Y, Wu F B, Zhang G P. Changes of organic acid exudation and rhizosphere pH in rice plants under chromium stress. Environmental Pollution, 2008, 155(2): 284-289.

[44] 刘雪. 抗砷细菌及根系有机酸对砷超富集植物蜈蚣草促生及吸砷机理研究 [D ]. 南京: 南京大学, 2017.

[45] 董子阳, 胡佳杰, 胡宝兰. 微生物铁载体转运调控机制及其在环境污染修复中的应用. 生物工程学报, 2019, 35(11)：2189-2200.

[46] 赵中秋, 崔玉静, 朱永官. 菌根和根分泌物在植物抗重金属中的作用. 生态学杂志, 2003, 22(6): 81-84.

[47] Hammer D, Keller C. Changes in the rhizosphere of metal-accumulating plants evidenced by chemical extractants. Journal of Environmental Quality, $2002,31(5): 1561-1569$.

[48] Jones D L, Darah P R, Kochian L V. Critical evaluation of organic acid mediated iron dissolution in the rhizosphere and its potential role in root iron uptake. Plant and Soil, 1996, 180(1) : 57-66.

[49] 何沅洁. 三峡库区消落带优势植物根系低分子量有机酸对土壤铅影响的模拟研究 [D ]. 重庆: 西南大学, 2017.

[50］林琦, 陈英旭, 陈怀满, 郑春荣. 根系分泌物与重金属的化学行为研究. 植物营养与肥料学报, 2003, 9(4): 425-431.

[51] D'Orazio V, Ghanem A, Senesi N. Phytoremediation of pyrene contaminated soils by different plant species. CLEAN-Soil, Air, Water, 2013, 41 (4) : 377-382

[52] 杨艳, 凌婉婷, 高彦征, 任丽丽, 张翼, 陈冬升. 几种多环芳烃的植物吸收作用及其对根系分泌物的影响. 环境科学学报, 2010, 30(3)： 593-599.

［53］许超, 林小方, 夏北成. 玉米幼苗根系分泌物对芘污染的响应. 生态学报, 2010, 30(12): 3280-3288.

[54] Přikryl Z, Vančura V. Root exudates of plants. Plant and Soil, 1980, 57(1): 69-83.

[55] 潘声旺, 袁馨, 刘灿, 李亚阑, 杨婷, 唐海云. 苯并 $[\alpha]$ 萠对不同修复潜力羊茅属植物的根系分泌物中几种低分子量有机物的影响. 植物 生态学报, 2016, 40(6) : 604-614.

[56] 谢晓梅, 廖敏, 杨静. 芘对黑麦草根系几种低分子量有机分泌物的影响. 生态学报, 2011, 31(24): 7564-7570.

[57] 丁克强, 骆永明, 刘世亮, 宋静, 吴龙华, 邢维芹, 李振高, 陶澍. 黑麦草对土壤中苯并 [a]芘动态变化的影响. 土壤学报, 2004, 41(3)： 348-353.

[58] Liu S L, Luo Y M, Cao Z H, Wu L H, Ding K Q, Christie P. Degradation of benzo $[a]$ pyrene in soil with arbuscular mycorrhizal alfalfa. 
Environmental Geochemistry and Health, 2004, 26(2): 285-293.

[59] 陈桐, 蔡全英, 吴启堂, 吕辉雄, 曾巧云, 李慧. PAEs 胁迫对高/低累积品种水稻根系形态及根系分泌低分子有机酸的影响. 生态环境学 报, 2015, 24(3): 494-500.

[60] Phillips L A, Greer C W, Farrell R E, Germida J J. Plant root exudates impact the hydrocarbon degradation potential of a weathered-hydrocarbon contaminated soil. Applied Soil Ecology, 2012, 52: 56-64.

[61] Singer A C, Smith D, Jury W A, Hathuc K, Crowley D E. Impact of the plant rhizosphere and augmentation on remediation of polychlorinated biphenyl contaminated soil. Environmental Toxicology and Chemistry, 2003, 22(9) : 1998-2004.

[62] 谢晓梅, 廖敏, 杨静. 黑麦草根系分泌物剂量对污染土壤芘降解和土壤微生物的影响. 应用生态学报, 2011, 22(10): 2718-2724.

[63] Luo L, Zhang S Z, Shan X Q, Zhu Y G. Oxalate and root exudates enhance the desorption of $p, p^{\prime}$-DDT from soils. Chemosphere, 2006, 63(8): 1273-1279.

[64] Gao Y Z, Ren L L, Ling W T, Gong S S, Sun B Q, Zhang Y. Desorption of phenanthrene and pyrene in soils by root exudates. Bioresource Technology, 2010, 101(4): 1159-1165.

[65］郭平, 王瑾, 康春莉, 顾斌, 刘德敏, 林学铎. 根系分泌物对五氯酚的增溶作用和影响机制. 环境化学, 2009, 28(4): 519-523.

[66] Leigh M B, Fletcher J S, Fu X, Schmitz F J. Root turnover: an important source of microbial substrates in rhizosphere remediation of recalcitrant contaminants. Environmental Science \& Technology, 2002, 36(7): 1579-1583.

[67] Kirk J L, Klironomos J N, Lee H, Trevors J T. The effects of perennial ryegrass and alfalfa on microbial abundance and diversity in petroleum contaminated soil. Environmental Pollution, 2005, 133(3) : 455-465.

[68] 潘声旺, 刘灿, 黄方玉, 李亚阑, 唐海云, 杨婷. 多环芳烃胁迫下根系分泌物对根际微生物降解效能的影响. 成都大学学报: 自然科学 版, 2016, 35(1): 86-89.

[69] 王悦, 郭美霞, 金京华, 巩宗强, 贾春云, 李晓军, 张巍. 三叶草根系分泌物对多环芳烃微生物降解及加氧酶的影响. 应用生态学报, 2014, 25(11) : 3145-3151.

[70] Segura A, Rodríguez-Conde S, Ramos C, Ramos J L. Bacterial responses and interactions with plants during rhizoremediation. Microbial Biotechnology, 2009, 2(4): 452-464.

[71］潘声旺, 雷志华, 吴云霄, 何茂萍. 苏丹草根分泌物在有机氯农药降解过程中的作用. 中国环境科学, 2017, 37(8): 3072-3079.

[72] 潘声旺, 刘灿, 黄方玉. 根系分泌物对土壤中有机氯农药降解的强化效应及其作用机制. 成都大学学报: 自然科学版, 2016, 35(2)： 196- 200.

[73] Rentz J A, Alvarez P J J, Schnoor J L. Benzo $[a]$ pyrene co-metabolism in the presence of plant root extracts and exudates: implications for phytoremediation. Environmental Pollution, 2005, 136(3): 477-484.

[74] 张银萍, 王芳, 杨兴伦, 谷成刚, 李杰, 蒋新. 土壤中高环多环芳烃微生物降解的研究进展. 微生物学通报, 2010, 37(2): 280-288.

[75] 巩宗强, 李培军, 王新, 张海荣, 宋玉芳, 李彬. 萠在土壤中的共代谢降解研究. 应用生态学报, 2001, 12(3): 447-450.

[76］刘世亮, 骆永明, 吴龙华, 宋静. 污染土壤中苯并 [a]蒈的微生物共代谢修复研究. 土壤学报, 2010, 47(2): 364-369.

[77] Compant S, Clément C, Sessitsch A. Plant growth-promoting bacteria in the rhizo- and endosphere of plants: their role, colonization, mechanisms involved and prospects for utilization. Soil Biology and Biochemistry, 2010, 42(5): 669-678.

[78] Canarini A, Kaiser C, Merchant A, Richter A, Wanek W. Root exudation of primary metabolites: mechanisms and their roles in plant responses to environmental stimuli. Frontiers in Plant Science, 2019, 10: 157.

[79] 安风秋. 外源重金属铅和镉对土壤生物活性及微生物群落多样性的影响研究 [D]. 杨凌: 西北农林科技大学, 2018.

[80］金婷婷, 刘鹏, 黄朝表, 王芳, 徐根娣, 黄佩娜. 铝胁迫下大豆根系分泌物对根际土壤微生态的影响. 土壤学报, 2008, 45(3): 526-534.

[81］丁淑兰. 重金属胁迫对刺槐一一根瘤菌共生体系的根系分泌物及土壤微生物多样性的影响 [D]. 杨凌: 西北农林科技大学, 2015.

[ 82] Kozdrój J, van Elsas J D. Response of the bacterial community to root exudates in soil polluted with heavy metals assessed by molecular and cultural approaches. Soil Biology and Biochemistry, 2000, 32(10): 1405-1417.

[83] 孙晨瑜, 曾燕红, 马俊卿, 刘璐, 王文奇, 黄京华. 丛枝菌根真菌对黄花蒿生长和根系分泌物化学组成的影响. 热带作物学报, 2020, 41 (9) : 1831-1837.

[84] 苏金豹, 王东亮, 杨立学. 落叶松四种根系分泌物对胡桃楸根系活力和菌根侵染率的影响. 生态学杂志, 2013, 32 (10): 2659-2664.

[85］施积炎, 陈英旭, 林琦, 王远鹏. 根分泌物与微生物对污染土壤重金属活性的影响. 中国环境科学, 2004, 24(3): 316-319.

[86] Sheng X F, He L Y, Wang Q Y, Ye H S, Jiang C Y. Effects of inoculation of biosurfactant-producing Bacillus sp. J119 on plant growth and cadmium uptake in a cadmium-amended soil. Journal of Hazardous Materials, 2008, 155(1/2): 17-22.

[87] Rajkumar M, Sandhya S, Prasad M N V, Freitas H. Perspectives of plant-associated microbes in heavy metal phytoremediation. Biotechnology Advances, 2012, 30(6) : 1562-1574.

[88] Jin C W, Li G X, Yu X H, Zheng S J. Plant Fe status affects the composition of siderophore-secreting microbes in the rhizosphere. Annals of 
Botany, 2010, 105(5): 835-841.

[ 89] Sun T R, Cang L, Wang Q Y, Zhou D M, Cheng J M, Xu H. Roles of abiotic losses, microbes, plant roots, and root exudates on phytoremediation of PAHs in a barren soil. Journal of Hazardous Materials, 2010, 176(1/3) : 919-925.

[90] Musilova L, Ridl J, Polivkova M, Macek T, Uhlik O. Effects of secondary plant metabolites on microbial populations: changes in community structure and metabolic activity in contaminated environments. International Journal of Molecular Sciences, 2016, 17 (8) : 1205.

[91] Ahmed M, Focht D D. Degradation of polychlorinated biphenyls by two species of Achromobacter. Canadian Journal of Microbiology, 1973, 19(1) : 47-52.

[92] Pradeep S, Josh M S, Hareesh E S, Kumar S, Benjamin S. Achromobacter denitrificans strain SP1 produces an intracellular esterase upon utilizing di (2ethylhexyl) phthalate. International Biodeterioration \& Biodegradation, 2015, 105: 160- 167.

[93] 许超, 夏北成. 运用多隔层根箱研究黑麦草根际微域中萠的降解. 土壤学报, 2009, 46(3): 426-433.

[94] Miya R K, Firestone M K. Enhanced phenanthrene biodegradation in soil by slender oat root exudates and root debris. Journal of Environmental Quality, 2001, 30(6): 1911-1918.

[95] Feng N X, Yu J, Zhao H M, Cheng Y T, Mo C H, Cai Q Y, Li Y W, Li H, Wong M H. Efficient phytoremediation of organic contaminants in soils using plant-endophyte partnerships. Science of the Total Environment, 2017, 583: 352-368.

[96] Fernandez O, Theocharis A, Bordiec S, Feil R, Jacquens L, Clément C, Fontaine F, Barka E A. Burkholderia phytofirmans PsJN acclimates grapevine to cold by modulating carbohydrate metabolism. Molecular Plant-Microbe Interactions ${ }^{\circledR}, 2012,25(4)$ : 496-504.

[97] Gao Y Z, Zhu L Z. Plant uptake, accumulation and translocation of phenanthrene and pyrene in soils. Chemosphere, 2004, 55(9) : 1169-1178.

[ 98 ] Cheng J J, Liu Y A, Wan Q, Yuan L, Yu X Y. Degradation of dibutyl phthalate in two contrasting agricultural soils and its long-term effects on soil microbial community. Science of the Total Environment, 2018, 640-641: 821-829.

[99] Techer D, D'Innocenzo M, Laval-Gilly P, Henry S, Bennasroune A, Martinez-Chois C, Falla J. Assessment of Miscanthus $\times$ giganteus secondary root metabolites for the biostimulation of PAH-utilizing soil bacteria. Applied Soil Ecology, 2012, 62: 142-146. 